\title{
Kanserli Hastalarda Hastalık Algısı ve Yaşam Kalitesi
}

\section{IIIness Perception and Quality of Life in Patients with Cancer}

\author{
Tuğba MENEKLI ${ }^{1}{ }^{(\mathbb{D})}$, Ferhan DOĞAN ${ }^{1}{ }^{(\mathbb{D})}$, Emin Tamer ELKIRAN 2
}

1 İnönü Üniversitesi Hemşirelik Fakültesi, İç Hastalıkları Hemşireliği AD. Malatya, TÜRKIYE

2 İnönü Üniversitesi Turgut Özal Tıp Merkezi, Tıbbi Onkoloji AD, Malatya, TÜRKIYE

\section{Öz.}

Amaç: Bu araştırma kanserli hastalarda hastalık algısını ve yaşam kalitesini incelemek amacıyla tanımlayıcı olarak yapılmış̧ır.

Materyal ve metod: Araştırmanın örneklemini Aralık 2019-Şubat 2020 tarihleri arasında bir eğitim araştırma hastanesinin onkoloji kliniğinde yatarak ve ayaktan tedavi gören 151 kanserli hasta oluşturmuştur. Veriler Kişisel Tanııı Formu, Hastalık Algııı Ölçeği (HAÖ), Yaşam Kalitesi İndeksi Kanser Versiyonu-III (QOL-CV) kullanılarak toplanmıştır. Veriler SPSS 25 programında tanımlayıcı istatistikler, Independent Samples $t$, Kruskal Wallis ve Mann- Whitney U ile değerlendirilmiştir. Bulgular: Hastaların \% 58.3' ünün kadın, \%29.1'inin kolon kanseri olduğu ve \%11.9'unun hastalık hakkında bilgi sahibi olmadığı bulunmuştur. HAÖ alt ölçeklerinden hastaların kişisel kontrol algısı puan ortalamasının (23.00 \pm 3.35$)$, QOL-CV alt ölçeklerinden ise aile alt ölçeği puan ortalamasının en yüksek (26.97 \pm 5.04 ) olduğu bulunmuştur. Toplam QOL-CV puan ortalaması ise $23.44 \pm 4.42$ olarak saptanmıştır.

Sonuç: Hastaların kişisel kontrol algısı ve yaşam kalitesi aile alt boyutu en yüksek, toplam yaşam kalitesi ise orta düzeydedir.

Anahtar Kelimeler: Kanser, Hastalık algısı, Yaşam kalitesi.

\section{Abstract}

Background: The purpose of this descriptive study is to determine the perception of iness and quality of life in patients with cancer.

Materials and Methods: The sample of the study consisted of 151 cancer patients who were inpatient and outpatient in the oncology clinic of an education and research hospital between December 2019 and February 2020. The data were collected using Personal Information Form, Iness Perception Scale (IPQ), Quality of Life Index-Cancer Version-III (QOL-CV). The data were evaluated in SPSS 25 program with descriptive statistics, Independent Samples t, Kruskal Wallis and Mann-Whitney U.

Results: It was found that $58.3 \%$ of the patients were female, $29.1 \%$ had colon cancer and $11.9 \%$ had no information about the ilness. It was found that the mean scores of the patients' perception of personal control $(23.00 \pm 3.35)$ from the IPQ subscales were the highest, and the family subscale mean score of the QOL-CV subscales was found to be the highest $(26.97 \pm 5.04)$. The total QOL-CV score was $23.44 \pm 4.42$.

Conclusion: It was determined that the patients' perception of internal control and quality of life family subscale was high also and their total quality of life was moderate.

Key words: Cancer, Illness perception, Quality of life.
Sorumlu Yazar I

Corresponding Author

\section{Dr. Öğr. Üyesi Tuğba MENEKLI}

İnönü Üniversitesi

Hemşirelik Fakültesi,

İç Hastalıkları Hemşireliği AD,

Bulgurlu Mahallesi, Elazığ Yolu 15.

Km., 44280

Merkez/Battalgazi/Malatya

e-mail: tugbamenekli2013@gmail.com

Tel: 05345820605

Geliş tarihi / Received: 14.10.2020

Kabul tarihi / Accepted: 18.12.2020

DOI: 10.35440 /hutfd.810484 


\section{Giriş}

Malign bir hastalık olan kanser; vücudun herhangi bir organ veya dokusunda anormal hücrelerin düzensiz ve kontrolsüz bir biçimde çoğalmasıyla meydana gelir (1). Kanser, erken teşhis ve tedavi edilmediğinde ölümle sonuçlanabilen bir sağlık sorunudur (2). Tüm ölüm nedenleri arasında ikinci sırayı alan kanser, gelişmiş ülkelerde ölümlerin \%25 'ini oluşturur (3).

Kanser ve tedavisi fiziksel, sosyal ve ruhsal iyilik halini etkileyerek, kişilerin yaşam kalitelerinin bozulmasına neden olmaktadır. Yaşam kalitesi; bireylerin yaşamdan doyum alması, fiziksel, psikolojik ve ekonomik açıdan yeterli olması, bireyler ile iyi ilişkiler içinde olması, kendilerini geliştirmeye ve eğlenmeye zaman ayırması olarak tanımlanır (4-6).

Hastalık algısı, hastaların bir hastalığa sahip olmasını nasıl değerlendirdikleri ile ilgili olup hastaların hastalık süreçleri, inançları, baş etme yöntemleri, maddi ve manevi değerleri üzerinde etkisi olan bir kavramdır $(4,5)$. Hastalık algısının belirlenmesi, kanser hastalarında var olan ve olası rahatsızlıkları daha iyi tanımlayabilmek, tedavi edebilmek, hemşirelik girişimlerini planlayabilmek ve sonuçlarını değerlendirebilmek açısından önemlidir $(3,6)$. Hastalık algılarının sorgulanması, bireylerin tedaviye uyumunun artmasını, hastalıklarını kontrol edebileceklerine inanmasını ve yaşam kalitesinin arttırmasını sağlayacaktır. Yapılan araştırmalar kanserli hastalarda, fiziksel sorunların yanı sıra, hastalık algısının da yaşam kalitesini etkilediğini göstermiştir $(1,5)$. Bu doğrultuda bakımın planlanması hastanın yaşam kalitesini yükseltmesine olanak sağlayacaktır $(3,7)$. Bu araştırma, kanser hastalarının hastalık algısı ile yaşam kalitesini incelemek amacıyla yapılmıştır.

\section{Materyal ve Metod \\ Araştırma türü}

Bu araştırma tanımlayıcı tiptedir.

\section{Araştırma Evreni ve Örneklemi}

Araştırma evrenini, Aralık 2019-Şubat 2020 tarihleri arasında, Malatya ilindeki üniversite hastanesinde, medikal onkoloji servisinde yatarak tedavi gören ve kemoterapi ünitesinde ayaktan tedavi gören kanser hastaları oluşturmuştur. Örneklemini ise, araştırmayı kabul eden ve araştırma alınma kriterine uyan 151 hasta oluşturmuştur. Örneklem hacminin hesaplanmasında power analizi kullanımıştır. $G$ power programında yapılan hesaplama ile araştırmanın gücü $\% 95$, alfa değeri 0.05 , etki düzeyi orta düzey kabul edilmiştir. Araştırmaya alınma kriterleri; 18 yaş ve üzeri, bilinci açık, iletişim kurmaya engel durumu ve mental rahatsızlığı bulunmayan, Türkçe okuma yazma bilen, en az 2 ay kanser tanısı alan, araştırmaya katılmayı kabul eden hastalardır.

\section{Veri Toplama Araçları}

Kişisel Tanııı Formu, Hastalık Algısı Ölçeği (HAÖ) ve Yaşam Kalitesi İndeksi -Kanser Versiyonu-III (QOL-CV) ölçeklerinden oluşmuştur.

\section{Kişisel Tanıtım Formu}

Araştırmacıların literatür tarayarak oluşturduğu formda, hastaya ait sosyodemografik özelliklerden oluşan 9 , hastalığa ait bilgilerden oluşan 10 olmak üzere toplam 19 sorudan oluşmaktadır.

\section{Hastalık Algısı Ölçeği (HAÖ)}

HAÖ, Weinmann ve arkadaşları tarafından geliştirimişstir (8). HAÖ, kanser, romatoid artrit, psöriyazis, diyabet, kronik akciğer hastalıkları ve kalp hastalıkları için kullanılmıştır. Moss-Morris ve arkadaşları tarafından yeniden revize edilmiştir (9). Ülkemizde kanser hastalarında ise Armay ve arkadaşları tarafından HAÖ geçerlik ve güvenirlik çalışması yapıımıştır (10).

HAÖ; hastalık tipi, hastalık hakkındaki görüşleri ve hastalık nedenleri alt ölçeğinden oluşmaktadır.

Hastalık tipi alt ölçeği: Sık görülen 14 hastalık belirtisini (ağrı, bulantı, kilo kaybı, yorgunluk, hırıltılı solunum, soluk almada güçlük, eklem sertliği, boğazda yanma, gözlerde yanma, uyku güçlüğü, baş ağrısı, mide yakınmaları, sersemlik hissi) içermektedir. Bu belirtilerin her biri için kişiye önce, 'hastalığın başlangıcından bu yana yaşayıp yaşamadığg', sonrasında ise 'bu belirtiyi hastalığıyla ilgili görüp görmediği' sorulmaktadır. Bu alt ölçek, her belirti için iki soruya da evet/hayır olarak yanıt verilecek biçimde düzenlenmiştir. İkinci sorudaki evet yanıtlarının toplamı hastalık tipi boyutunun değerlendirme sonucunu oluşturmaktadır (10).

Hastalık hakkındaki görüşleri alt ölçeği: Beşli likert tipi, 38 maddeden oluşmaktadır. Süre (akut/kronik), kişisel kontrol, sonuçlar, hastalığı anlayabilme, tedavi kontrolü, duygusal temsiller ve süre (döngüsel) olarak yedi alt ölçekten oluşmaktadır. Süre alt ölçeği, kişinin hastalığının süresiyle ilişkilidir ve akut, kronik, döngüsel olarak gruplanır. Sonuçlar alt ölçeği, kişinin hastalığının şiddetini, psikolojik, fiziksel, sosyal ve işlevselliğine olası etki inançlarını inceler. Kişisel kontrol, kişinin hastalığının tedavisi, seyri, süresi ve üzerindeki iç kontrol algısını değerlendirir. Tedavi kontrolü, kişiye uygulanan tedavinin etkinliği hakkındaki inançlarını araştırır. Hastalığı anlayabilme, kişinin hastalığını ne kadar anladığını veya kavradığını araştııı. Duygusal temsiller, kişinin hastalığıyla ilgili hissettiklerini araşsııı (10).

Hastalık nedenleri alt ölçeği: Beşli likert tipi, 18 maddeden oluşmaktadır ve hastalıkların olası nedenlerini içermektedir. Psikolojik atıflar, risk etkenleri, bağışıklık, kaza veya şans alt ölçeklerinden oluşan bu alt ölçek; kişinin hastalığının olası nedenleri hakkındaki düşüncelerini araşıımaya yöneliktir (8). Ölçeğin Türkçe geçerlik güvenirliğinin yapıdığı çalışmada, Cronbach's Alpha değeri hastalık hakkında görüşler boyutu için 0.69-0.77 hastalık nedenleri boyutu için 0.25-0.72 olarak belirtilmiştir (2). Bu araştırmada ise hastalık hakkında görüşler boyutunun Cronbach's Alpha değeri 0.64-0.90; hastalık nedenleri boyutunun ise 0.500.62 arasında olduğu bulunmuştur. 
Yaşam Kalitesi Endeksi Kanser Uyarlaması-III (QOLCV) QOL-CV, Ferrans ve Powers tarafından geliştirilmiş̧ir, Türkçe geçerlik ve güvenirliği Can ve arkadaşları tarafından yapılımıştı $(11,12)$. Ölçek, 6 dereceli likert tipinden oluşan maddelere verilen yanıtlarla cevaplanır ve yaşamın çeşitli alanlarından 'memnuniyet' ile, o alanın kişi için 'önemini' ölçen her biri 33 maddeyi kapsayan iki ana bölümden oluşur. Sağlık ve hareketlilik, sosyo-ekonomik, psikolojikinançlar ve aile olmak üzere toplam dört alt ölçeğinden oluşur. Toplam yaşam kalitesi puanı ve alt grup puanları memnuniyet puanlarını önem puanlarına uyarlayarak elde edilir. Ölçekten 0-30 arası puan alınmaktadır (12). Can ve ark. tarafından Cronbach's Alfa değeri alt ölçeği için ayrı ayrı hesaplanarak 0.63-0.85 arasında bulunmuştur (11). Bu araştırmada ise Cronbach's Alfa değeri 0.60-0.79 arasında bulunmuştur.

\section{Verilerin Analizi ve Değerlendirilmesi}

Veri analizi SPSS 25.0 paket programı kullanılarak yapımıştır. Hastaların tanıtıcı ve hastalığa ait özellikleri için sayı ve yüzdelik testi kullanılmıştır. Verilerin normallik analizi için Kolmogorov-Smirnov Uyum Iyiliği Testi uygulanmıştır. Sürekli sayısal değişkenlerde normal dağılıma uygun olanlar için ortalama \pm standart sapma (SD), normal dağılıma uygun olmayanlar için ortanca ve çeyrekler arası açıklık (IQR) kullanılmıştır.

Çoklu grup ortalamalarının karşılaşıırılması için normal dağılım göstermeyen verilerde Kruskal Wallis testi; ikili grup ortalamalarının karşılaştııılması için normal dağılım göstermeyenlerde Mann- Whitney U testi, normal dağılım gösterenlerde ise Independent Samples t testi kullanılmıştır. Değerlendirilmelerde $p<0.05$ değeri istatistiksel açıdan anlamlı kabul edilmiştir.

\section{Araştırmanın Etik Boyutu}

Araştırma verilerinin toplandığı Turgut Özal Tıp Merkezi başhekimliğinden, İnönü Üniversitesi Etik Kurulu'ndan yazılı izin (Karar No: 2020/354), çalışmaya katılmayı kabul eden kanser hastalarından ise bilgilendirilmiş sözlü onam alınmıştır.

\section{Bulgular}

Araştırmaya katılan kanser hastalarının tanıtıcı özelliklerinin dağılımı tablo 1'de görülmektedir( Tablo 1).

HAÖ hastalık tipi alt ölçeğinde; hastalığın başlangıcından itibaren en çok yorgunluk (\%84.5) kilo kaybı (\%75.5) belirtilerini yaşadığı ve bu belirtilerin (kilo kaybı $\% 74.5$, yorgunluk \%82.5) hastalıkları ile ilgili olduğunu bildirdikleri bulunmuştur. Hastaların en az ise eklem sertliği (\%9.3) ve gözlerde yanma (\%9.3) belirtilerini yaşadığı bulunmuş olup yaşanan bu belirtilerin (gözlerde yanma \%25.6, eklem sertliği $\% 30.5$ ) hastalıkları ile ilişkilendirdikleri saptanmıştır. Hastalık tipi alt ölçeğine ait 14 belirtiden kanserle ilişkili olarak deneyimlen belirti sayısı ortalamasının $8.60 \pm 2.01$ olduğu bulunmuştur.
Tablo 1. Kanser Hastalarının Tanıııcı Özelliklerinin Dağıımı

\begin{tabular}{|c|c|c|}
\hline Tanıtıcı Özellikleri & $\mathrm{X} \pm \mathrm{SD}$ & \\
\hline Yaş Ortalaması & $46.79 \pm 3.61$ & \\
\hline Cinsiyet & $\mathrm{n}$ & $\%$ \\
\hline Kadın & 88 & 58.3 \\
\hline Erkek & 63 & 41.7 \\
\hline Eğitim Durumu & & \\
\hline Illköğretim & 104 & 68.9 \\
\hline Ortaöğretim & 32 & 21.2 \\
\hline Lise & 12 & 7.9 \\
\hline Lisans & 2 & 1.3 \\
\hline Yüksek Lisans & 1 & 0.7 \\
\hline Doktora & 0 & 0 \\
\hline Medeni Durum & & \\
\hline Evli & 95 & 62.9 \\
\hline Bekar & 56 & 37.1 \\
\hline Meslek & & \\
\hline Yok & 6 & 4.0 \\
\hline İşçi & 11 & 7.3 \\
\hline Memur & 3 & 2.0 \\
\hline Serbest Meslek & 32 & 21.2 \\
\hline Ev Hanımı & 45 & 29.8 \\
\hline Emekli & 54 & 35.8 \\
\hline Ekonomik Durum & & \\
\hline Gelir Giderden Az & 54 & 35.8 \\
\hline Gelir Gidere Dengeli & 85 & 56.3 \\
\hline Gelir Giderden Fazla & 12 & 7.9 \\
\hline Aile Tipi & & \\
\hline Çekirdek Aile & 115 & 76.2 \\
\hline Geniş Aile & 36 & 23.8 \\
\hline Yaşadığı Yer & & \\
\hline Köy & 40 & 26.5 \\
\hline İ & 32 & 21.2 \\
\hline illçe & 79 & 52.3 \\
\hline Sosyal Güvence Var & & \\
\hline Var & 129 & 85.4 \\
\hline Yok & 22 & 14.6 \\
\hline Hastalık Bilgisi & & \\
\hline Var & 133 & 88.1 \\
\hline Yok & 18 & 11.9 \\
\hline Hastalık Hakkında B & lağı & \\
\hline Yok & 18 & 11.9 \\
\hline Doktor & 121 & 80.1 \\
\hline Hemşire & 0 & 0 \\
\hline Eş-Anne-Baba & 6 & 4.0 \\
\hline Medya & 6 & 4.0 \\
\hline Ailede Başka Kanse & & \\
\hline Var & 56 & 37.1 \\
\hline Yok & 95 & 62.9 \\
\hline İlaçların Yan Etkisin & Rahatsızlık Durumu & \\
\hline Evet & 61 & 40.4 \\
\hline Hayır & 90 & 59.6 \\
\hline Kronik Hastalık Varl & & \\
\hline Evet & 58 & 38.4 \\
\hline Hayır & 93 & 61.6 \\
\hline Hastalık Türü & & \\
\hline Hematolojik Kanser & 13 & 8.6 \\
\hline Mide Kanseri & 30 & 19.8 \\
\hline Kolon Kanseri & 44 & 29.1 \\
\hline Akciğer Kanseri & 23 & 15.2 \\
\hline Meme Kanseri & 30 & 19.9 \\
\hline Baş Boyun Kanseri & 11 & 7.3 \\
\hline
\end{tabular}




\begin{tabular}{lll}
\cline { 1 - 1 } \multicolumn{1}{c}{ Tablo 1 devamı } & & \\
Hastalık Evresi & & 36.4 \\
Evre I & 55 & 36.4 \\
Evre II & 55 & 20.5 \\
Evre III & 31 & 6.6 \\
Evre IV & 10 & \\
Metastaz Varlı̆ı & & 32.5 \\
Var & 49 & 67.5 \\
Yok & 102 & \\
\hline
\end{tabular}

SD: Standart Sapma X: Ortalama

Tablo 2. Hastaların HAÖ ve QOL-CV Puan Ortalaması

\begin{tabular}{|c|c|c|c|}
\hline & $\mathrm{X} \pm \mathrm{SD}$ & $\begin{array}{l}\text { Madde } \\
\text { Sayısı }\end{array}$ & $\begin{array}{l}\text { Ölçekten Alınan } \\
\text { En Düşük ve En } \\
\text { Yüksek Değerler }\end{array}$ \\
\hline \multicolumn{4}{|c|}{$\begin{array}{l}\text { Hastalık Algısı Ölçeği (HAÖ) } \\
\text { Hastalık Hakkındaki Görüşler Alt Ölçeği }\end{array}$} \\
\hline Süre (Akut/Kronik) Algısı & $17.00 \pm 6.72$ & 6 & $6-30$ \\
\hline Sonuçlar Algısı & $16.03 \pm 4.09$ & 6 & $8-30$ \\
\hline Kişisel Kontrol Algısı & & 6 & $6-30$ \\
\hline Tedavi Kontrolü Algısı & $15.53 \pm 2.04$ & 5 & $5-25$ \\
\hline Hastalığı Anlayabilme Algısı & $13.11 \pm 3.92$ & 5 & $5-25$ \\
\hline Süre (Döngüsel) Algısı & $14.00 \pm 4.00$ & 4 & $4-20$ \\
\hline \multicolumn{4}{|l|}{ Olası Nedenler Alt Ölçeği } \\
\hline Psikolojik Faktörler & $18.09 \pm 2.99$ & 5 & $6-28$ \\
\hline Risk Faktörleri & $15.20 \pm 3.87$ & 8 & $8-26$ \\
\hline Bağışıklık & $5.70 \pm 2.35$ & 2 & $2-10$ \\
\hline Kaza ya da Şans & $4.88 \pm 2.11$ & 2 & $2-9$ \\
\hline \multicolumn{4}{|c|}{ Yaşam Kalitesi İndeksi -III(QOL-CV) } \\
\hline Sağlık ve Hareketlilik & $19.64 \pm 4.77$ & 13 & $0-30$ \\
\hline Sosyal ve Ekonomi & $20.53 \pm 4.90$ & 8 & $0-30$ \\
\hline Psikolojik ve Dinsel & $20.05 \pm 4.31$ & 7 & $0-30$ \\
\hline Aile & $26.97 \pm 5.04$ & 5 & $0-30$ \\
\hline Toplam QOL-CV & $23.44 \pm 4.42$ & 33 & $0-30$ \\
\hline
\end{tabular}

SD: Standart Sapma, X: Ortalama

HAÖ: Hastalık Algısı Ölçeği, QOL-CV: Yaşam Kalitesi Endeksi Kanser Uyarlamasi-IIII

Hastalık hakkındaki görüşleri alt ölçeğinde; hastaların Kişisel Kontrol Algısı puan ortalamalarının (23.00 \pm 3.35$)$ en yüksek, Hastalığı Anlayabilme Algısı puan ortalamaların ise en düşük $(13,11 \pm 3,92)$ olduğu bulunmuştur. Hastaların Olası Nedenleri alt ölçeğinde; Psikolojik Faktörler alt ölçeğinin puan ortalaması en yüksek $(18.09 \pm 2.99)$ olarak bulunmuştur. Hastaların QOL-CV dağılımları incelendiğinde; Sağlık ve Hareketlilik alt ölçeği puan ortalaması (19.64 \pm 4.77$)$ en düşük, Aile alt ölçeği puan ortalaması ise en yüksek (26.97 \pm 5.04$)$ hesaplanmıştır. Toplam QOL-CV puanı 23.44 \pm 4.42 olarak saptanmıştır ( Tablo 2).

Hastaların HAÖ Hastalık Hakkındaki Görüşler boyutuna bakıldığında; Süre (akut/kronik) alt ölçeği ile medeni durum ve kronik hastalık varlığı; Sonuçlar alt ölçeği puan ortalaması ile hastalık tipi puan ortalaması arasındaki fark istatistiksel olarak anlamlı bulunmuştur $(p<0.05)$. Ayrıca Duygusal Temsiller alt ölçeği puan ortalaması ile hastalık tipi puan ortalaması arasındaki fark da istatistiksel olarak anlamlı bulunmuştur $(p<0.05)$ (Tablo3).

Hastaların QOL-CV Sağlık ve Hareketlilik alt ölçeği puan ortalaması ile kronik hastalık varlığı; QOL-CV ölçeği Sosyal ve Ekonomi alt ölçek puan ortalaması ile aile tipi, kronik hastalık varlığı; QOL-CV ölçeği Psikoloji ve Dinsel alt ölçek puan ortalaması ile cinsiyet ve hastalık tipi; QOL-CV ölçeği Aile alt ölçek puan ortalaması ile medeni durum; QOL-CV ölçeği toplam puan ortalaması ile aile tipi, kronik hastalık varlığı puan ortalamaları arasındaki fark istatistiksel olarak anlamlı bulunmuştur $(p<0.05)$ (Tablo 4).

\section{Tartışma}

Kanser hastalarının hastalık algısı ve yaşam kalitesi arasındaki ilişkiyi incelemek amacıyla yapılan araştırmanın bulguları, literatür kapsamında tartışımıştır.

Hastaların en çok yorgunluk belirtisini yaşadığı ve bu hastaların neredeyse tamamının ise bu belirtiyi hastalıkla ilişkilendirdiği saptanmıştır. Bu araştırmanın sonucu kanser hastaları ile yapılan çalışma sonuçları ile benzerlik göstermektedir (13-15).Yorgunluk, kanserli hastalarda 1/3 oranında görülmektedir ve hastaların fiziksel sağlığını etkileyen en önemli belirtidir (15).

Araştırmada hastaların belirti sayısı ortalamasının $8.60 \pm 2.01$ olduğu tespit edilmiştir. Beyin tümörü ve özofagus kanserli hastalarda yapılan çalışmada da hastaların hastalığa yönelik belirti ortalamalarının sırasıyla $8.13 \pm 3.90 ; 7.39 \pm 5.57$ olduğu bulunmuştur $(16,17)$. Bu durumun kanserin prognozundan, tedavisinin yan etkilerinden, olası acil komplikasyonlardan ve hastaların uzun süredir belirtileri deneyimlemesinden kaynaklandığını düşündürmektedir.

Hastalık Hakkındaki Görüşler boyutu Kişisel Kontrol alt ölçeğinin puan ortalamasının en yüksek olduğu bulunmuştur. Bu sonuç; hastaların hastalık süresi, prognozu ve tedavisi üzerindeki iç kontrol algısının yüksek olduğunu göstermektedir. Literatür incelendiğinde; kanserli hastaların Kişisel Kontrol Algısı puanlarının genel olarak düşük olduğu belirtilmektedir $(18,19)$. Hastalar hastalık tanısı alır almaz hastalıkları üzerinde kontrol mekanizması kurmaya ve kişisel kontrollerini artırmaya çalışırlar. Özellikle ülkemizde hastalık sürecinde hastaya manevi ve fiziksel destek daha fazla artmaktadır. Araştırmanın yapıldığı yöre dikkate alındığında, kültürel açıdan gelişmekle beraber halen geleneksel aile yapısının devam ettiği bir şehirdir. Bu faktörler hastaların hastalığı üzerindeki kontrol algısının artmasına neden olabilir (16, 20, 21). Araştırmaya katılan hastaların Hastalığı Anlayabilme alt ölçeğinin puan ortalamasının en düşük olduğu bulunmuştur. Bu sonuç hastaların hastalığıyla ilgili yeterli düzeyde bilgilendirilmediklerini göstermektedir. Ayrıca, araştırmaya katılan hastalara kanser hakkında verilen bilgileri hastanın anlayıp anlamadığının geri bildirim olarak değerlendirilmemesinden kaynaklandığını düşündürmektedir. Literatüre göre, kanser hastalarında çoğunlukla Hastalığı Anlayabilme Algısı puan ortalamasının düşük olduğunu belirten çalışmaların (22-24) yanı sıra yüksek olduğunu belirleten çalışmalar da bulunmaktadır $(25,26)$. Kanserli hastalara ne kadar fazla bilgi verilirse olumlu hastalık algısı o kadar fazla gelişmektedir $(27,28)$. Hastaların Hastalık Nedenleri boyutu Psikolojik Faktörler 
alt ölçeğinin puan ortalamasının en yüksek, Kaza ve ya Şans alt ölçeğinin puan ortalamasının ise en düşük olduğu bulunmuştur. Hastaların hastalığına ilişkin nedenleri ve sonuçları hakkında düşüncesini kendisinin ve çevresinin deneyimleri etkilemektedir. Hastalıkla ilgili bireysel algılarının yanı sıra kültürel yansımalar da hastalık algısının belirlenmesinde önemlidir. Türk toplumunda hastalı̆ıın nedenlerine bakıldığında kültürün bir parçası olarak stres, mutsuzluk ve anksiyete ile ilişkilendirilmekte ve kaza veya şans faktörünün önemli olmadığı düşünülmektedir $(24,26)$.

Bu araştırmada QOL-CV Sağlık ve Hareketlilik alt ölçek puan ortalaması düşük Aile alt ölçek puan ortalaması yüksektir. Bu durum hastaların kanserden kaynaklanan fizyo- lojik değişiklik ve tedavilere bağlı gelişebilen halsizlik, yorgunluk, bulantı, kusma, kan değerlerindeki düşmeye bağlı olarak gelişen fiziksel kapasitelerinde ve yeterliliklerindeki bozulma ile açıklanabilir $(22,29)$. Ayrıca kanser, kişinin sadece fiziksel ve psikolojik sağlığını değil, aile sistemini de etkilemektedir (30). Aile üyelerinden biri ölümcül bir hastalığa yakalandığında, aile üyelerinin hepsinin yaşam tarzını, rol ve görevlerini, beklentilerini yeniden değerlendirmesi ve hasta olan yakınına destek vermesi yaşam kalitesini yükseltmektedir $(30,31)$. Bu araştırma da hastanın yakınlarının destek olmasının yaşam kalitesine katkı sağladığı düşünülmektedir.

Tablo 3. Hastaların Tanıtıcı ve Hastalık Özelliklerine Göre Hastalık Hakkındaki Görüşler Alt Ölçek Puan Ortalamasının Dağılımı

\begin{tabular}{|c|c|c|c|c|c|c|c|c|}
\hline Özellikler & $n$ & $\begin{array}{l}\text { Süre } \\
\text { (Akut/Kr) }\end{array}$ & Sonuçlar & $\begin{array}{l}\text { Kişisel Kont- } \\
\text { rol }\end{array}$ & $\begin{array}{l}\text { Tedavi Kont- } \\
\text { rolü }\end{array}$ & $\begin{array}{l}\text { Hastalığı Anla- } \\
\text { yabilme }\end{array}$ & $\begin{array}{l}\text { Süre Dön- } \\
\text { güsel }\end{array}$ & $\begin{array}{l}\text { Duygusal Tem- } \\
\text { siller }\end{array}$ \\
\hline & Cinsiyet & $\mathrm{X} \pm \mathrm{SD}$ & $\mathrm{X} \pm \mathrm{SD}$ & $\mathrm{X} \pm \mathrm{SD}$ & $\mathrm{X} \pm \mathrm{SD}$ & $X \pm S D$ & $\mathrm{X} \pm \mathrm{SD}$ & $\mathrm{X} \pm \mathrm{SD}$ \\
\hline Kadın & 88 & $15.06 \pm 5.90$ & $22.34 \pm 4.09$ & $22.00 \pm 4.61$ & $21.00 \pm 3.64$ & $15.06 \pm 3.78$ & $15.01 \pm 3.97$ & $24.11 \pm 4.08$ \\
\hline Erkek & 63 & $14.00 \pm 5.24$ & $22.05 \pm 4.16$ & $22.97 \pm 4.99$ & $21.13 \pm 4.08$ & $15.99 \pm 4.08$ & $15.00 \pm 4.44$ & $23.99 \pm 5.07$ \\
\hline \multicolumn{9}{|l|}{ Medeni Durum } \\
\hline $\begin{array}{l}\text { Evli } \\
\text { Bekâr } \\
\text { p }^{*}\end{array}$ & $\begin{array}{l}95 \\
56\end{array}$ & $\begin{array}{c}15.90 \pm 3.45 \\
12.80 \pm 4.66 \\
0.217\end{array}$ & $\begin{array}{l}23.74 \pm 3.55 \\
22.12 \pm 4.10 \\
0.603\end{array}$ & $\begin{array}{l}23.77 \pm 4.25 \\
23.06 \pm 5.08 \\
0.501\end{array}$ & $\begin{array}{l}20.55 \pm 4.05 \\
21.04 \pm 4.12 \\
0.307\end{array}$ & $\begin{array}{l}16.00 \pm 4.75 \\
15.90 \pm 3.08 \\
0.335\end{array}$ & $\begin{array}{l}15.00 \pm 3.15 \\
15.02 \pm 3.02 \\
0.090\end{array}$ & $\begin{array}{l}21.90 \pm 6.00 \\
21.03 \pm 6.93 \\
0.104\end{array}$ \\
\hline \multicolumn{9}{|l|}{ Aile Tipi } \\
\hline $\begin{array}{l}\text { Çekirdek Aile } \\
\text { Geniş Aile } \\
\text { p }^{*}\end{array}$ & $\begin{array}{l}115 \\
36\end{array}$ & $\begin{array}{l}15.01 \pm 5.77 \\
16.99 \pm 4.37 \\
0.197\end{array}$ & $\begin{array}{l}22.00 \pm 3.77 \\
22.70 \pm 3.90 \\
0.785\end{array}$ & $\begin{array}{l}22.31 \pm 5.91 \\
22.80 \pm 5.07 \\
0.906\end{array}$ & $\begin{array}{l}21.90 \pm 4.40 \\
21.07 \pm 4.03 \\
0.552\end{array}$ & $\begin{array}{l}15.08 \pm 4.09 \\
15.00 \pm 5.34 \\
0.314\end{array}$ & $\begin{array}{l}14.90 \pm 3.04 \\
15.05 \pm 3.33 \\
0.086\end{array}$ & $\begin{array}{l}21.84 \pm 6.05 \\
21.04 \pm 6.12 \\
0.301\end{array}$ \\
\hline \multicolumn{9}{|c|}{ Ailede Başka Kanser Varlığı } \\
\hline $\begin{array}{l}\text { Var } \\
\text { Yok } \\
\mathbf{p}^{*}\end{array}$ & $\begin{array}{l}56 \\
95\end{array}$ & $\begin{array}{l}15.00 \pm 4.32 \\
15.88 \pm 5.0900 .874\end{array}$ & $\begin{array}{l}22.60 \pm 5.16 \\
23.57 \pm 4.46 \\
0.103\end{array}$ & $\begin{array}{l}23.00 \pm 4.07 \\
23.58 \pm 5.07 \\
0.705\end{array}$ & $\begin{array}{l}21.11 \pm 2.91 \\
21.23 \pm 4.06 \\
0.416\end{array}$ & $\begin{array}{l}15.20 \pm 4.33 \\
15.01 \pm 5.02 \\
0.864\end{array}$ & $\begin{array}{l}14.92 \pm 4.06 \\
14.06 \pm 3.71 \\
0.151\end{array}$ & $\begin{array}{c}21.07 \pm 6.00 \\
21.67 \pm 6.13 \\
0.135\end{array}$ \\
\hline & & $\begin{array}{l}\text { Median } \\
\text { (IQR25-75) }\end{array}$ & $\begin{array}{l}\text { Median } \\
\text { (IQR25-75) }\end{array}$ & $\begin{array}{l}\text { Median } \\
\text { (IQR25-75) }\end{array}$ & $\begin{array}{l}\text { Median } \\
\text { (IQR25-75) }\end{array}$ & $\begin{array}{l}\text { Median } \\
\text { (IQR25-75) }\end{array}$ & $\begin{array}{l}\text { Median } \\
\text { (IQR25-75) }\end{array}$ & $\begin{array}{l}\text { Median } \\
\text { (IQR25-75) }\end{array}$ \\
\hline \multicolumn{9}{|l|}{ Hastalık Tipi } \\
\hline Hematolojik Kan- & 13 & 14(13-17) & $15(10-26)$ & $24(8-22)$ & $16(5-21)$ & $16(5-21)$ & $13(5-18)$ & $14(6-21)$ \\
\hline ser & 30 & $13(11-15)$ & 18(12-30) & $20(8-28)$ & $22(12-24)$ & $15(10-25)$ & $15(4-19)$ & $15(8-23)$ \\
\hline Mide Kanseri & 44 & 13(1215) & $16(7-23)$ & $21(7-23)$ & $20(6-26)$ & $14(6-20)$ & $14(6-20)$ & $16(6-22)$ \\
\hline Kolon Kanseri & 23 & $14(11-17)$ & $19(9-21)$ & $20(10-30)$ & $10(5-15)$ & $14(5-19)$ & $16(4-20)$ & $12(6-18)$ \\
\hline Akciğer Kanseri & 30 & 15(13-17) & $23(20-26)$ & $21(9-30)$ & $24(7-25)$ & $15(8-23)$ & $12(6-18)$ & $19(10-29)$ \\
\hline Meme Kanseri & 11 & $15(14-20)$ & $20(10-30)$ & $23(6-29)$ & $16(8-24)$ & $16(5-22)$ & $14(5-19)$ & $14(7-20)$ \\
\hline $\begin{array}{l}\text { Baş Boyun Kan- } \\
\text { seri } \\
\mathbf{p}^{* *}\end{array}$ & & 0.208 & 0.046 & 0.939 & 0.027 & 0.698 & 0.165 & 0.011 \\
\hline \multicolumn{9}{|c|}{ Kronik Hastalık Varlığı } \\
\hline Var & 58 & $19(6-21)$ & $18(10-26)$ & $24(8-16)$ & $15(5-24)$ & $15(6-22)$ & $15(11-19)$ & $21(18-23)$ \\
\hline Yok & 93 & $16(7-24)$ & $15(8-24)$ & $23(6-28)$ & $14(7-22)$ & $12(9-15)$ & $12(4-20)$ & $17(6-28)$ \\
\hline $\mathrm{p}^{\star \star \star}$ & & 0.420 & 0.727 & 0.365 & 0.943 & 0.321 & 0.085 & 0.137 \\
\hline & & $\mathrm{Z}: 1.893$ & $Z: 1.204$ & $Z: 1.034$ & $Z: 0.966$ & $\mathrm{Z}: 1.572$ & $Z: 1.268$ & $Z: 0.861$ \\
\hline
\end{tabular}


Tablo 4. Hastaların Tanıtıcı ve Hastalık Özelliklerine Göre QOL-CV Ölçeğinin Puan Ortalamasının Dağııımı

\begin{tabular}{|c|c|c|c|c|c|c|}
\hline Özellikler & $\mathrm{n}$ & Sağlık ve Hareketlilik & Sosyal ve Ekonomi & Psikolojik ve Dinsel & Aile & $\begin{array}{l}\text { QOL-CV } \\
\text { Toplam }\end{array}$ \\
\hline & & $\mathrm{X} \pm \mathrm{SD}$ & $\mathrm{X} \pm \mathrm{SD}$ & $X \pm S D$ & $\mathrm{X} \pm \mathrm{SD}$ & $\mathrm{X} \pm \mathrm{SD}$ \\
\hline \multicolumn{7}{|l|}{ Cinsiyet } \\
\hline Kadın & 88 & $19.07 \pm 6.33$ & $19.43 \pm 3.80$ & $20.31 \pm 4.09$ & $19.69 \pm 3.24$ & $17.00 \pm 5.46$ \\
\hline Erkek & 63 & $20.90 \pm 5.25$ & $20.51 \pm 3.05$ & $17.05 \pm 4.02$ & $20.84 \pm 4.02$ & $22.08 \pm 5.22$ \\
\hline$p^{*}$ & & 0.770 & 0.124 & 0.025 & 0.867 & 0.030 \\
\hline \multicolumn{7}{|l|}{ Medeni Durum } \\
\hline Evli & 95 & $18.52 \pm 5.97$ & $20.62 \pm 4.35$ & $20.25 \pm 5.19$ & $20.39 \pm 4.28$ & $21.04 \pm 4.38$ \\
\hline Bekar & 56 & $18.60 \pm 5.02$ & $21.72 \pm 4.68$ & $19.70 \pm 5.60$ & $15.31 \pm 4.70$ & $18.11 \pm 5.47$ \\
\hline $\mathrm{p}^{*}$ & & 0.705 & 0.244 & 0.191 & 0.040 & 0.020 \\
\hline \multicolumn{7}{|l|}{ Aile Tipi } \\
\hline Çekirdek Aile & 115 & $16.75 \pm 5.11$ & $20.88 \pm 4.90$ & $20.51 \pm 5.90$ & $20.65 \pm 3.44$ & $19.00 \pm 3.62$ \\
\hline Geniş Aile & 36 & $17.32 \pm 5.07$ & $17.10 \pm 4.14$ & $19.67 \pm 5.22$ & $20.73 \pm 4.67$ & $18.10 \pm 4.02$ \\
\hline$p^{*}$ & & 0.924 & 0.022 & 0.135 & 0.518 & 0.755 \\
\hline \multicolumn{7}{|c|}{ Ailede Başka Kanser Varlığı } \\
\hline Var & 56 & $15.06 \pm 5.54$ & $19.12 \pm 4.75$ & $20.91 \pm 4.10$ & $19.41 \pm 4.02$ & $22.90 \pm 4.03$ \\
\hline Yok & 95 & $15.99 \pm 6.05$ & $20.57 \pm 4.46$ & $21.07 \pm 4.08$ & $19.30 \pm 4.01$ & $21.96 \pm 4.03$ \\
\hline \multirow[t]{2}{*}{$p^{*}$} & & 1.120 & 1.857 & 0.737 & 1.501 & 1.646 \\
\hline & & $\begin{array}{l}\text { Median } \\
\text { (IQR25-75) }\end{array}$ & $\begin{array}{l}\text { Median } \\
\text { (IQR25-75) }\end{array}$ & $\begin{array}{l}\text { Median } \\
\text { (IQR25-75) }\end{array}$ & $\begin{array}{l}\text { Median } \\
\text { (IQR25-75) }\end{array}$ & $\begin{array}{l}\text { Median } \\
\text { (IQR25-75) }\end{array}$ \\
\hline \multicolumn{7}{|l|}{ Hastalık Tipi } \\
\hline Hematolojik Kanser & 13 & $22(6-18)$ & $19(10-28)$ & $10(5-15)$ & $26(18-30)$ & $24(17-30)$ \\
\hline Mide Kanseri & 30 & $16(10-22)$ & $20(11-19)$ & $11(7-15)$ & $25(20-30)$ & $23(11-25)$ \\
\hline Kolon Kanseri & 44 & $18(9-27)$ & $21(18-24)$ & $14(8-20)$ & $26(21-29)$ & $21(16-26)$ \\
\hline Akciğer Kanseri & 23 & $21(14-28)$ & $17(10-24)$ & $12(5-19)$ & $24(14-30)$ & $22(14-30)$ \\
\hline Meme Kanseri & 30 & $20(13-29)$ & $21(16-27)$ & $20(10-30)$ & $23(18-28)$ & $23(17-28)$ \\
\hline Baş Boyun Kanseri & 11 & $19(10-28)$ & $18(6-30)$ & $11(8-14)$ & $25(20-30)$ & $20(15-25)$ \\
\hline$p^{* *}$ & & 0.184 & 0.652 & 0.040 & 0.841 & 0.217 \\
\hline \multicolumn{7}{|c|}{ Kronik Hastalık Varlığı } \\
\hline Var & 58 & $14(8-20)$ & $15(6-24)$ & $18(7-28)$ & $24(18-26)$ & $20(5-30)$ \\
\hline Yok & 93 & $24(20-28)$ & $26(22-30)$ & $19(6-30)$ & $25(16-28)$ & $28(22-30)$ \\
\hline \multirow{2}{*}{$\mathrm{p}^{\star \star \star}$} & & 0.020 & 0.031 & 0.309 & 0.418 & 0.043 \\
\hline & & $Z: 4.540$ & $Z: 4.103$ & $Z: 3.817$ & $Z: 3.699$ & $Z: 4.605$ \\
\hline
\end{tabular}

SD: Standart Sapma X: Ortalama *Independent Samples $t$ test ${ }^{\star \star}$ Kruskal Wallis Testi ${ }^{\star \star \star}$ Mann- Whitney U Testi

Evli hastaların ve kronik hastalığı olanların Süre (akut/kronik) alt ölçeği puan ortalamasının daha yüksek olduğu bulunmuştur. Süre (akut/kronik) alt ölçeğinden kişinin yüksek puan alması hastalığını kronik olarak gördüğünü göstermektedir. Kanser sadece kişinin fiziksel ve ruhsal bütünlüğünü etkilemez ailenin de bütünlüğünü tehdit eder (32). Evli hastalar kendileriyle beraber ailelerini de düşünmekte ve aile içindeki rollerini yerine getirememe endişesi yaşamaktadırlar. Bu durum da hastaların travmalarını daha uzun ve yoğun yaşamasına neden olmaktadır. Bu nedenlere bağlı olarak evli hastaların Süre (akut/kronik) alt ölçeğinin puan ortalamasının yüksek olduğu belirtilmektedir $(29,32)$.

Baş-boyun kanseri olan hastaların Sonuçlar alt ölçeği puan ortalamasının daha yüksek olduğu bulunmuştur. Keeling ve ark. baş-boyun kanserli hastaların Sonuçlar alt ölçeği puan ortalamalarını diğer kanser türlerine göre daha düşük bulmuş ancak gruplar arası farkı istatistiksel olarak anlamlı bulmamıştır (33). Baş-boyun kanseri tanısı sürecinde tümörler beyin dokusuna yayıldığından, cerrahi tedavi yapılamamaktadır. Bu gruptaki hastaların Sonuçlar alt ölçeği puan ortalamalarının yüksek çıkmış olmasının nedeni sadece tedavisi mümkün olmayan kanser belirtileriyle değil aynı zamanda nüks tehlikesiyle karşı karşıya olmalarından kaynaklanmış olabilir $(26,29)$.

Meme kanseri tanılı hastaların Tedavi Kontrol alt ölçeği puan ortalamasının daha yüksek olduğu bulunmuştur. Kişinin Tedavi Kontrolü Algısından yüksek puan alması uygulanan tedaviyi kontrol edebildiğine ilişkin olumlu inançları olduğunu göstermektedir. Meme kanseri, fiziksel, psikolojik, mesleki ve cinsel açıdan uyum bozukluğu yaratan bir hastalıktır. Araştırmaya katılan meme kanserli hastaların tamamının kadınlardan oluşması, kadınların memeyi sadece süt verme fonksiyonu olarak değil, kadınlık, çekicilik ve cinsellik sembolü olarak da görmeleriyle alakalı olabileceğini düşündürmektedir. Bu nedenle meme hastalıkları, ilgili doku-organı etkilemenin dışında emosyonel ve psikolojik olarak da hastayı etkiler $(18,23)$. Bu gruptaki hastaların tedavi ile ilgili pozitif inançları bu nedenlerle yüksek çıkmış olabilir. Meme kanserli kadın hasta, öncelikle cinsel olarak eşine beden imajı açısından çevresine karşı mahcubiyet içerisinde hissetmemek için tedavi sürecini 
daha iyi kontrol edebilmek ister ve bunun için diğer kanser tanısı olan hastalara göre süreci yakından takip eder (32, 34). Ayrıca bu araştırma da meme kanserli hastaların Duygusal Temsiller Algısı puan ortalaması diğerlerine göre daha yüksek bulunmuştur. Bu sonuç meme kanserli hastaların hastalığa ilişkin olumsuz duyguları yoğun olarak algıladığını göstermektedir. Psikososyal rehabilitasyon uygulanan meme kanserli hastalarla yapılan çalışmada; uygulama öncesinde hastaların Duygusal Temsiller alt ölçek puanlarının diğer boyutlara göre daha yüksek bulunduğu belirtilmiştir. Bu grup hasta da özellikle olumlu duyguların oluşturulmasını sağlamaya yönelik girişimlerin yapılması önerilmektedir (7, 29, 31- 34).

Yaşam kalitesi kavramı birçok faktörün etkileşimi ile şekillenmektedir ve sürekli değişiklik gösterme eğilimdedir. Bunu belirleyen etkenler, bireyin fiziksel durumu, psikolojik durumu, spiritüel algılar, ekonomik boyut, sosyal boyut gibi pek çok bileşeni barındırmaktadır $(7,20)$. Araştırmamızda, Sağılık ve Hareketlilik alt ölçeği kronik hastalığı olmayanlarda daha yüksek bulunmuştur. Tek başına bile tedavisi zor olan kanser, kronik hastalığın eklenmesi ile birlikte hastanın daha çok sağığını bozmakta ve hareket ile ilgili yaşam kalitesini düşürmektedir $(11,35)$. Sosyal ve Ekonomi alt ölçek puanı çekirdek ailesi olanlarda daha yüksek olduğu saptanmıştır. Bu sonucun, çekirdek ailesi olan hastaların geniş ailesi olanlara göre giderlerinin daha az olması ile ilişkili olduğunu düşündürmektedir. Psikolojik ve Dinsel alt ölçek puanı kadınlarda meme kanseri tanısı alanlarda yüksek bulunmuştur. Bu sonuç; araştırmanın büyük çoğunluğunu kadınların oluşturması, kadınların erkeklere göre psikolojik ve dinsel konularda daha fazla ilgili olması ayrıca meme kanserli hastaların kadınlardan oluşması ile ilişkilidir. Aile alt ölçeği puanı evlilerde yüksek bulunmuştur. Evli olan hastaların hastalık sürecinde devamlı eş ve çocuk desteğinin olmasının aile yaşam kalitesi puanını arttırdığını düşündürmektedir. QOL-CV toplam puanı erkeklerde evli olanlarda kronik hastalı̆ı̆ olmayanlarda daha yüksek bulunmuştur. Kadınların kanseri daha yoğun yaşaması duygusal olarak daha hassas olması, erkeklerden daha fazla rol ve sorumluluklarının olması, bekârların kendilerine bakma ve kişisel bakımlarını sürdürme konusunda yetersiz olması, sağlık problemlerine gereken ilgiyi göstermemeleri yaşam kalitesini düşürmektedir. Ayrıca kronik hastalığa sahip olmak, hastalık belirtileri ile mücadele etmek, tedavinin getirdiği problemler ya da engeller, gelecekte yaşanacak sorunlar gibi birçok negatif duygu bireyin hem fiziksel hem psikolojik hem de sosyal açıdan yaşamını olumsuz etkileyerek yaşam kalitesini düşürür $(31,34,35)$.

Sonuç

Sonuç olarak, hastaların Kişisel Kontrol algısı puan ortalamalarının yüksek, Hastalığı Anlayabilme puan ortalamalarının ise en düşük olduğu bulunmuştur. Hastaların tanıtıcı ve hastalığa ilişkin özellikleri hastalık algısı ve yaşam kalitesini etkilemektedir. Kanser hastalarının yaşam kalitesini artırmak için; hastaların takip ve tedavi sürecinde hastalık algılarının, belirtilerinin ve hastalıkları hakkındaki görüşlerinin sorgulanması ve değerlendirilmesi önerilmektedir.

Etik onam: Araştırma verilerinin toplandı̆̆ı Turgut Özal Tıp Merkezi başhekimliğinden, İnönü Üniversitesi Etik Kurulu'ndan yazılı izin (Karar No: 2020/354), çalışmaya katılmayı kabul eden kanser hastalarından ise bilgilendirilmiş sözlü onam alınmıştır.

\section{Kaynaklar}

1. Akın S, Can G, Aydıner A, Özdilli K, Durna Z. Quality of life symptom experience and distress of lung cancer patients undergoing chemotherapy. European Journal Of Oncology Nursing. 2010;14: 400-409.

2. Armay Z, Özkan M, Kocaman N, Özkan S. Hastalık algısının ölçeğinin kanser hastalarında türkçe geçerlik ve güvenirlik çalışması. Klinik Psikiyatri. 2007; 10:192-200.

3. Leventhal H, Leventhal EA, Cameron L. Representations, procedures, and affect in illness self-regulation: a perceptualcognitive model. In: Baum A, Revenson TA, Singer JE, Editors. Handbook Of Health Psychology. Mahwah: Lawrence Erlbaum; 2001;19-48.

4. Çalışkan T, Duran S, Karadaş A, Ergün S., Tekir Ö. Kanser hastalarının yaşam kalitesi ve sosyal destek düzeylerinin değerlendirilmesi. KÜ Tıp Fak Dergisi. 2015; 17(1): 27-36.

5. Çavuşoğlu H. Onkolojik Hastalıklar. Çavuşoğlu H, Akın S, Alican I, Dreskeneli GS. Çev-ed. Cecil Essentials Of Medicine , 8.Baskı, Nobel Kitapevi, İstanbul, 2015 : 485-512.

6. Karabulutlu YE, Okanlı A. Hemodiyaliz hastalarında hastalık algısının değerlendirilmesi. Anadolu Hemşirelik Ve Sağlık Bilimleri Dergisi. 2011; 4-14.

7. Ashley L, Marti J, Jones H, Velikova G, Wright E. Illness perceptions within 6 months of cancer diagnosis are an independent prospective predictor of future health-related quality of life 15 months post-diagnosis. Psycho-Oncology. 2015; 24: 1463-70.

8. Kocaman N. Hastalık Algısı Ölçeği'nin türkçe uyarlamasının geçerlilik ve güvenirliği. Anadolu Psikiyatri Dergisi.2007; 8: 271-280.

9. Morris R, Weinman J, Petrie Kj, Horne R, Cameron Ld, Buick D. The revised illness perception. Psychology And Health 2002;17: 1-16.

10. Armay, Z. Hastalık algısı ölçeğinin geçerlilik ve güvenilirlik çalışması. Yüksek Lisans Tezi, İstanbul: İstanbul Üniversitesi Sağlık Bilimleri Enstitüsü, 2006.

11. Can G, Durna Z, Aydıner A. The validity and reliability of the Turkish version of the quality of life index [QII](Cancer Version) Eur J Oncol Nurs 2010;14: 316-321.

12. Ferrans C, Powers M. Quality of life index: development and psychometric properties. Adv Nurs Sci 8, 1985;15-24.

13. Fischer Mj, Wiesenhaan Me, Heijer Ad, Kleijn Wc, Nortier Jwr, Kaptein Aa. From Despair To Hope: A longitudinal study of illness perceptions and coping in a psycho-educational group intervention for women with breast cancer. Br J Health Psychol 2013; 18: 526-45.

14. Ma C, Yan J, Wu Y, Huang W. Illness perceptions of chinese women with breast cancer and relationships with socio-demographic and clinical characteristics. Int J Nurs Pract. 2018;24:12677. Doi: 10.1111/jin.12677.

15. Zordan R, Manitta V, Nandurkar H, Cole-Sinclair M, Philip J. Prevalence and predictors of fatigue in haemo-oncological patients. Internal Medicine Journal 2014;44(10):1013-1017.

16. Dempster M, Mccorry KN, Brennan E, Donnelly M, Murray LJ, Jonston TB. Do changes in illness perceptions predict changes in psychological distress among oesophageal cancer survivors. J Health Psychology 2010;16(3):500-509.

17. Keeling M, Bambroigh J, Simpson J. Depression, anxiety and positive affect in people diagnosed with low-grade tumours: the role of illness perceptions. Psycho-Oncology 2013;22(6):1421-1427. 
18. Freeman-Gibb LA, Janz NK, Katapodi MC, Zikmund-Fisher BJ, Northouse $L$. The relationship between illness representations, risk perception and fear of cancer recurrence in breast cancer survivors. Psychooncology. 2017;26:1270-1277. Doi: 10.1002/Pon.4143.

19. Thomson AK, Heyworth JS, Girschik J, Slevin T, Saunders C, Fritschi L. Beliefs and perceptions about the causes of breast cancer: a case-control study. BMC Res Notes. 2014;7:558. Doi: 10.1186/17560500-7-558.

20. Karabulutlu YE, Karaman S. Evaluation of cancer patients perception of illness. HSP. 2015;2:271-284.

21. Mccorry KN, Dempster M,Quinn J,Hogg A, Newell J, Moore M et all. Illness perception clusters at diagnosis predict psychological distress among women with breast cancer at 6 months post diagnosis. PsychoOncology 2013;22(3):692-698.

22. Gibbons A, Groarke A. Can risk and illness perceptions predict breast cancer worry in healthy women. J health psychol. 2016;21:20522062.

23. Emotional distress and dysfunctional illness perception are associated with low mental and physical quality of life in Chinese breast cancer patients. Health Qual Life Outcomes. 2017 Dec 1;15(1):231.

24. Zhang N, Fielding R, Soong I, Chan KK, Tsang J, Lee V, Lee C, Ng A, Sze WK, Tin P, Lam WW. Illness perceptions among cancer survivors. support care cancer. 2016;24:1295-1304. Doi: 10.1007/S00520015-2914-3.

25. Johansson AC, Axelsson M, Berndtsson I, Brink E. Illness perceptions in relation to experiences of contemporary cancer care settings among colorectal cancer survivors and their partners. Int J Qual Stud Health Well-Being And Well-Being. 2014;9:23581.

26. Karabulutlu YE, Karaman S. Kanser hastalarında hastalık algısının değerlendirilmesi. Sağlık Bilimleri Ve Meslekleri Dergisi 2015; 2: 27184.

27. Lan M, Zhang L, Zhang Y, Yan J. The relationship among illness perception, coping and functional exercise adherence in chinese breast cancer survivors. J Advanced Nursing. 2019;75(1): 75-84.

28. Ovayolu Ö. Onkolojik Sorunlar Ve Hemşirelik Yönetimi. Ovayolu N, Ovayolu Ö ed. Temel lç Hastalıkları Hemşireliği Ve Farkı Boyutlarıyla Kronik Hastalıklar, 1. Baskı, Çukurova Nobel Tıp Kitabevi, Adana, 2015: 460-88.

29. Sevimli Ş, Sağlıker Y. Neoplastik Hastalıklar. Sağlıker Y, Sarıca Y, İnal TC, ve Ark. Çev-ed. Harrison İç Hastalıkları Prensipleri, Nobel Kitapevi, İstanbul, 2013: 491-531.

30. Sarenmalm EK, Öhlen J, Jonsson T, Gaston-Johanson F. Coping With Recurrent Breast Cancer: Predictors Of Distressing Symptoms And Health-Related Quality Of Life. Journal Of Pain And Symptom Management.2007;34 (1):24-39.

31. Richters A, Derks J, Husson O, Et Al. Effect Of Surgical Magrin Status After Radical Prostatectomy On Health-Related Quality Of Life And IIIness Perception In Patients With Prostate Cancer. Urol. Oncol. 2015; 33: 9-15.

32. Husson O, Thong MSY, Molls F, Oerlemans S, Kaptein AA, Pollfranse LV. Illness Perceptions İn Cancer Survivors: What Is Role Of Information Provision? Psycho-Oncology 2013, 22: 490-8. 56.

33. Keeling M, Bambroigh J, Simpson J. Depression, Anxiety And Positive Affect In People Diagnosed With Low-Grade Tumours: The Role Of Illness Perceptions. Psycho-Oncology 2013;22(6):1421-1427.

34. Salonen $P$, Kellokumpu-Lehtınen PL, Huhtala H, Kaunonen M. The Quality Of Life And Social Support In Significant Others Of Patients With Breast Cancer - A Longitudinal Study. European Journal Of Cancer Care, 2014; 23: 274-283

35. Özçınar B, Güler SA, Özmen V, ve ark. Meme Kanserinde Lokal/Bölgesel Tedavi Sonrası Görülen Komplikasyonlar Ve Bunların Hasta Yaşam Kalitesi Üzerine Etkileri. The Journal Of Breast Health.2010;6 (1): 9-16.18. 